\title{
50. PRELIMINARY LIPID ANALYSES OF CORE SECTIONS 18, 24, AND 30 FROM HOLE 402A
}

\author{
P.J. Barnes, S.C. Brassell, P. Comet, G. Eglinton, J. McEvoy, J.R. Maxwell, A.M.K. Wardroper, and J.K. Volkman, \\ Organic Geochemistry Unit, School of Chemistry, University of Bristol, Bristol, England
}

\section{INTRODUCTION}

A preliminary analysis of the solvent-extractable lipids from three samples from the Aptian-Albian core sections of Hole 402A, which was drilled on the mid-continental slope of the Bay of Biscay $\left(47^{\circ} 52.48^{\prime} \mathrm{N}, 08^{\circ} 50.44^{\prime} \mathrm{W}\right)$, has been carried out. The aliphatic and aromatic hydrocarbons, carboxylic acids and free hydroxy acids have been examined by gas chromatography and gas chromatography-mass spectrometry.

A list of the samples is given in Table 1, together with relevant background data taken from the Summary Log. Core 402A-18 was a composite sample of Sections 1-4, obtained via the Institut Français du Pétrole; Cores 402A-24 and 30 were collected from the Scripps Institute of Oceanography. An additional core, 401-5 (supplied in a frozen state by the shipboard geochemist via British Petroleum Ltd.), was extracted, but the low concentrations of extractable lipids at comparable concentrations to a blank analysis precluded further investigations.

A preliminary attempt has been made to relate the extractable lipids of these black shales to the extent of diagenesis/maturation and to the paleoenvironment of deposition.

\section{EXPERIMENTAL PROCEDURES}

\section{General}

Cores 402A-24 and 30 and Core 401-5 were kept frozen until extraction; Core $402 \mathrm{~A}-18$ was supplied in a freeze-dried state.

All operations prior to GC were carried out in a clean room equipped with a filter unit (Microflow Pathfinder Ltd.) to remove continuously all particles $>0.5 \mu \mathrm{m}$ from the incoming air stream. Nylon gowns, hats, overshoes, and gloves were worn and the room was frequently vacuum cleaned; a fume hood (Bigneat Ltd.) circulated air through molecular sieve to remove contaminants and solvent vapors. All solvents were Mallinckrodt Nanograde and examined for purity by concentration $100 \mathrm{ml}$ to $20 \mu \mathrm{l}$ ) and analysis by GC as described below. Glassware was cleaned by boiling in detergent (Decon 90), rinsing $(\times 6)$ in double-distilled water (distilled from $\left.\mathrm{KOH} / \mathrm{KMnO}_{4}\right)$, heating $\left(3 \mathrm{hr}, 600^{\circ} \mathrm{C}\right.$ ) and finally, rinsing twice with methanol and twice with dichloromethane immediately before use. Pasteur pipettes and glass vials were heated at $600^{\circ} \mathrm{C}$ and rinsed as above; caps were lined with P.T.F.E. discs washed in dichloromethane. Double distilled water was extracted with dichloromethane before use. Concentrated $\mathrm{HCl}$, mercury, aluminum foil, and glass wool were extracted with dichloromethane and the glass wool heated $\left(600^{\circ} \mathrm{C}\right)$; fused
TABLE 1

Sediment Data for Samples Examined

\begin{tabular}{|c|c|c|c|}
\hline $\begin{array}{c}\text { Sample } \\
\text { (Interval in cm) }\end{array}$ & $\begin{array}{l}\text { Mean Depth } \\
(\mathrm{m})\end{array}$ & Age & Lithology \\
\hline $402 \mathrm{~A}-18-1,4$ & $298-308$ & Albian & $\begin{array}{l}\text { Composite of carbonaceous marly } \\
\text { limestone and carbonaceous } \\
\text { calcareous mudstone }\end{array}$ \\
\hline $402 \mathrm{~A}-24-1,0-20$ & 360 & Lower Albian & Carbonaceous marly limestone \\
\hline $402 \mathrm{~A}-30-1,65-75$ & 420 & Upper Aptian & Carbonaceous marly chalk \\
\hline $\begin{array}{l}401-5-1,1-5 \\
\text { (all } 0-5 \text { ) }\end{array}$ & $113-122$ & Mid Eocene & Nannofossil chalk \\
\hline
\end{tabular}

$\mathrm{KOH}$ was dissolved in water to yield a 60 per cent solution and was extracted with dichloromethane. The boron trifluoride/methanol complex was found to be sufficiently clean in the volumes used and the bis(trimethylsilyl)trifluoroacetamide contained only minor amounts of low molecular weight components that did not interfere with the analyses of alcohols. Silica-gel thin layers were purified by continuous elution in ethyl acetate $(>20 \mathrm{hr})$ and removal of contaminated gel. The $\mathrm{N}_{2}$ for solvent evaporation was "oxygen-free" grade and was passed through activated molecular sieve $(5 \AA)$. Extracted fractions were stored in dichloromethane (ca. $50 \mu \mathrm{l}$ ).

\section{Extraction (Figure 1)}

After thawing (ca. $1 \mathrm{hr}$ ) each sample was pulverized. The lipids were extracted with dichloromethane/methanol $(\times 2$, $2: 1,200 \mathrm{ml}$ ) by ultrasonication (10 $\mathrm{min}$, Dawe Soniprobe $7533 \mathrm{~A}$, equipped with Microtip) with cooling (ice-bath). ${ }^{1}$ After centrifugation (10 min; $2500 \mathrm{rpm})$, the yellow-brown supernatants were decanted; the extraction was repeated with $100 \mathrm{ml}$ solvent and the combined extracts concentrated at $30^{\circ} \mathrm{C}$ under water pump vacuum. The residues from solvent extraction were stored at $-20^{\circ} \mathrm{C}$ after drying.

The extract was saponified $(6 \% \mathrm{KOH}$ in methanol; $5 \mathrm{ml}$ ) by leaving to stand overnight at ambient in the dark under $\mathrm{N}_{2}$. The insoluble residues after extraction were dried, weighed, and stored for further analysis. Water $(6 \mathrm{ml})$ was added and the neutral lipids were extracted in dichloromethane $(3 \times 3 \mathrm{ml})$, washed with water $(4 \mathrm{ml})$ and the water washings combined with the aqueous fraction. The neutral extract was evaporated to dryness at $30^{\circ} \mathrm{C}$. The aqueous solution was acidified $(p \mathrm{H} 1)$ with concentrated $\mathrm{HCl}$ and extracted with dichloromethane $(3 \times 3 \mathrm{ml})$.

\footnotetext{
'Sections 402A-18-1 to 4, supplied as a freeze-dried residue by Dr. B. Tissot, was extracted with hexane/ propan-2-ol (1:4) and was saponified as above; the acid and non-saponifiable fractions were treated as above except that elemental sulfur was removed during the TLC separations.
} 


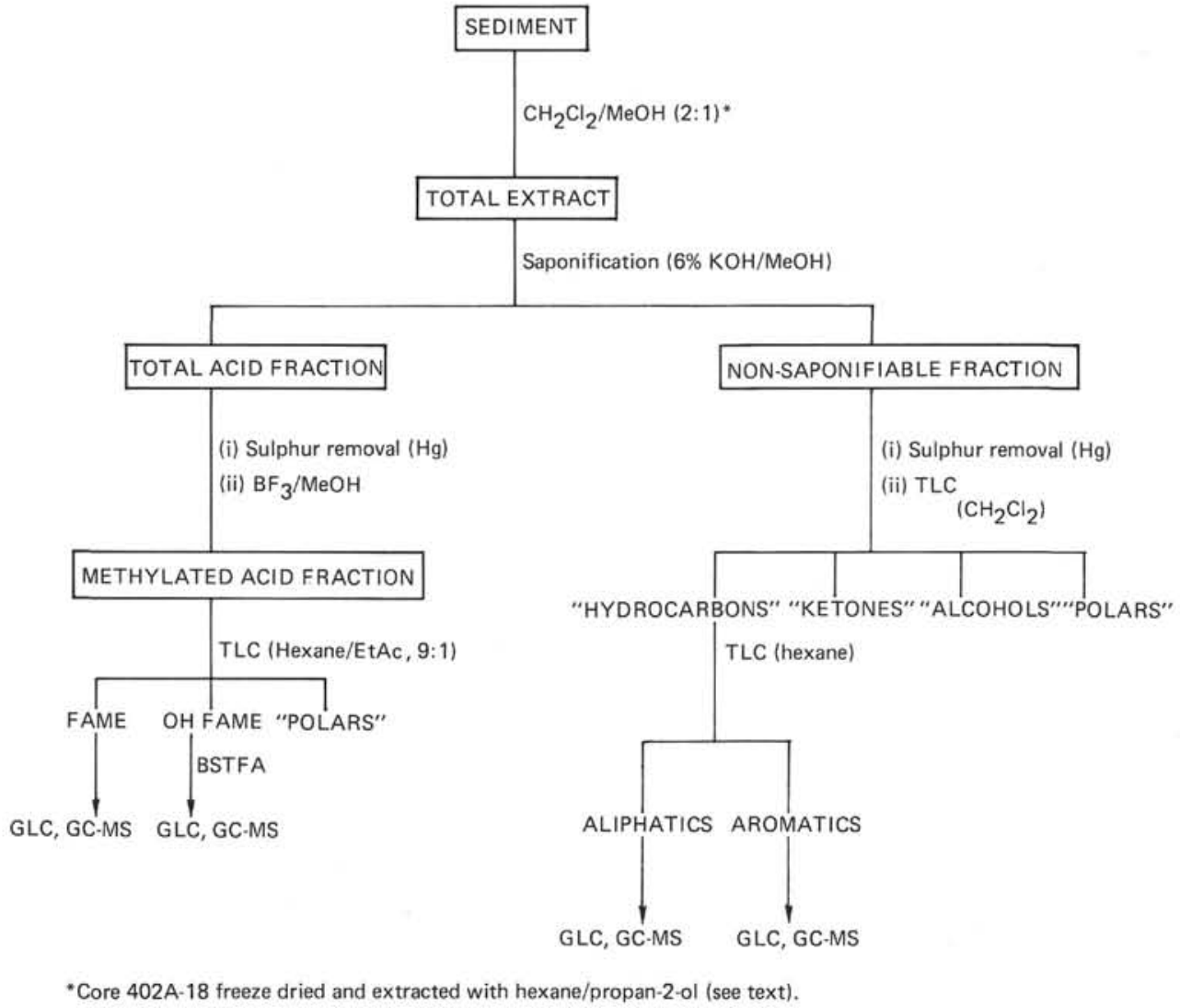

Figure 1. Analytical scheme for the extractable lipids of core samples from Hole $402 \mathrm{~A}$.

Sulfur was removed from acid and non-saponifiable fractions by shaking with elemental mercury (lg) and hexane $(1 \mathrm{ml})$, allowing the sulfide precipitate to settle $(>3 \mathrm{hr}$ ), and removing the supernatant. The precipitate was washed with hexane $(\times 2 ; 2 \mathrm{ml})$ and the complete procedure was repeated with a further aliquot of mercury; the hexane layers were combined and evaporated under $\mathrm{N}_{2}$. Boron trifluoride/ methanol complex $(14 \%, 0.2 \mathrm{ml})$ was added to the total acid fraction and the mixture heated $\left(70^{\circ} \mathrm{C} ; 5 \mathrm{~min}\right)$. Water was added to the methyl esters extracted into dichloromethane $(3 \times 1 \mathrm{ml})$, followed by solvent evaporation under $\mathrm{N}_{2}$.

\section{Thin-Layer Chromatography (TLC) (Figure 1)}

The non-saponifiable and methylated total acid (FAME) fractions were further separated on silica gel G $(0.25 \mathrm{~mm})$ with dichloromethane, and with hexane/ethyl acetate (9:1) as developers, respectively. Separated fractions were located (UV light; $254 \mu \mathrm{m}$, Rhodamine 6G in ethanol), and fractions were collected from the total non-saponifiables as follows: $\mathrm{Rf}=0.75-1.00(\mathrm{Rf}=$ tetracosane standard $)$, 0.20-0.75 (includes ketones), 0.05- 0.20 ( $\mathrm{Rf}=$ cholesterol), 0.0-0.05. Fractions were collected from the FAME as follows: $\mathrm{Rf}=0.65-1.00(\mathrm{Rf}=$ methylstearate standard), 0.05-0.65 (includes hydroxy acids, OH FAME), $0.0-0.05$. The hydrocarbons were further separated into aliphatic and aromatic fractions with hexane as developer, by comparison with authentic standards (tetracosane and pyrene).
All TLC fractions were collected from the silica gel by elution with dichloromethane $(10 \mathrm{ml})$. Separated fractions containing OH FAME and alcohols, respectively, were silylated with bis(trimethylsilyl)trifluoroacetamide ( $20 \mu \mathrm{l} ; 5$ min, ambient).

\section{Control Experiments}

For each sample, the entire analytical sequence (except for GC-MS) was carried out in parallel under identical conditions except that no core sample was present.

\section{Gas-Liquid Chromatography (GLC)}

Analyses were carried out on a Carlo Erba FV2151 equipped with an SL490 splitless injector, under the following conditions: $10 \mathrm{~m} \times 0.25 \mathrm{~mm}$ glass coated with OV- 1,60 to $260^{\circ} \mathrm{C}$ at $6 \% \mathrm{~min}$, after $1 \mathrm{~min}$, at ambient, 0.4 $\mathrm{kp} / \mathrm{cm}^{2} \mathrm{~N}_{2}$, injector $275^{\circ} \mathrm{C}$, detector $275^{\circ} \mathrm{C}$.

\section{Combined Gas Chromatography-Mass Spectrometry (GC-MS)}

Analyses were carried out on a Finnigan 4000 GC-MS coupled via a Finnigan interface to a DEC PDP-8e computer (M.J. Humberston, unpublished results) under the following conditions: column $20 \mathrm{~m} \times 0.32 \mathrm{~mm}$ i.d. glass coated with OV-1 (Jaeggi), programmed from 120 to $260^{\circ} \mathrm{C}$ at $6^{\circ}$ or $8 \% \mathrm{~min}$, flow rate ca. $2 \mathrm{ml} / \mathrm{min} \mathrm{He}$, source $250^{\circ} \mathrm{C}$, filament current $250 \mu \mathrm{A}$, electron energy $35 \mathrm{eV}$, scan rate $2.5 \mathrm{sec}$. 


\section{RESULTS}

For Cores 402A-24 and 402A-30, all of the blank fractions equivalent to the fractions examined (aliphatic hydrocarbons, aromatic hydrocarbons, FAME and $\mathrm{OH}$ FAME) showed virtually no measurable contaminants by GLC analysis (under identical conditions) of injection volumes equivalent to those used for the fractions themselves. The same situation applied to the aliphatic hydrocarbon and OH FAME blanks of Core 402A-18; the aromatic hydrocarbon blank showed two components which were not aromatic hydrocarbons. The FAME blank of 402A-18 contained $n-\mathrm{C}_{16: 0}, n-\mathrm{C}_{16: 1}, n-\mathrm{C}_{18: 0}$, and $n-\mathrm{C}_{18: 1}$ at concentrations half those observed in the sample; the distributions for Core 18 FAME are corrected accordingly.

Quantities of individual fractions were too low for accurate weighing; Table 2 shows the concentrations of selected individual components in the fractions, expressed as $\mathrm{ng} / \mathrm{g}$ extracted sediment (dry weight). Although only a few components have been quantitated, Table 2 shows that Core 402A-30 has the highest concentration of extractable lipids.

In this preliminary study, tentative structural assignments are based mainly on relative retention times and comparison of full mass spectra with authentic standards (where available), comparison with literature spectra or spectral interpretation. Distributions of compound classes for comparison between samples were obtained by examination of the appropriate mass fragmentograms.

\section{Aliphatic Hydrocarbons}

\section{Normal and Branched Alkanes}

The distributions of $n$-alkanes in the three samples range from $\mathrm{C}_{13}$ to $\mathrm{C}_{34}$ (402A-18), $\mathrm{C}_{16}$ to $\mathrm{C}_{34}$ (402A-24), and $\mathrm{C}_{15}$ to $\mathrm{C}_{34}(402 \mathrm{~A}-30)$ with $\mathrm{CPI}$ values of $1.07,1.38$, and 2.14 , respectively (Figure 2). All show bimodal distributions maximizing at $\mathrm{C}_{16}$ or $\mathrm{C}_{19}$ and $\mathrm{C}_{25}$ or $\mathrm{C}_{27}$, with a smooth distribution of lower molecular weight components. Core 18 shows the highest relative abundances of $n-C_{13}$ to $C_{17}$,

TABLE 2

Concentrations ${ }^{\mathrm{a}}$ of Selected Individual Lipids in Core Samples From Hole 402A

\begin{tabular}{lrrr}
\hline & \multicolumn{3}{c}{ Sample } \\
\cline { 2 - 4 } & $18-1$ to 4 & $24-1$ & $30-1$ \\
\hline Aliphatic Hydrocarbons & & & \\
$n$-C $17: 0$ & 17 & 4 & 11 \\
$n-C_{18: 0}$ & 13 & 8 & 15 \\
Hop-17(21)-ene & 32 & 27 & 60 \\
$\quad$ 17 $\beta$ H-homohopane & 86 & 66 & 160 \\
Aromatic Hydrocarbons & & & \\
$\quad$ Perylene & 0.5 & $\mathrm{~b}$ & $\mathrm{~b}$ \\
FAME & & & \\
$n$ n-C $16: 0$ & 11 & 3 & 12 \\
$n-\mathrm{C}_{24: 0}$ & 4 & 0.15 & 10 \\
\hline
\end{tabular}

${ }^{a}$ Nannogram of component/g dry weight extracted sediment; based on GLC peak height relative to a standard.

${ }^{b}$ Concentration too low for quantitation by GLC.
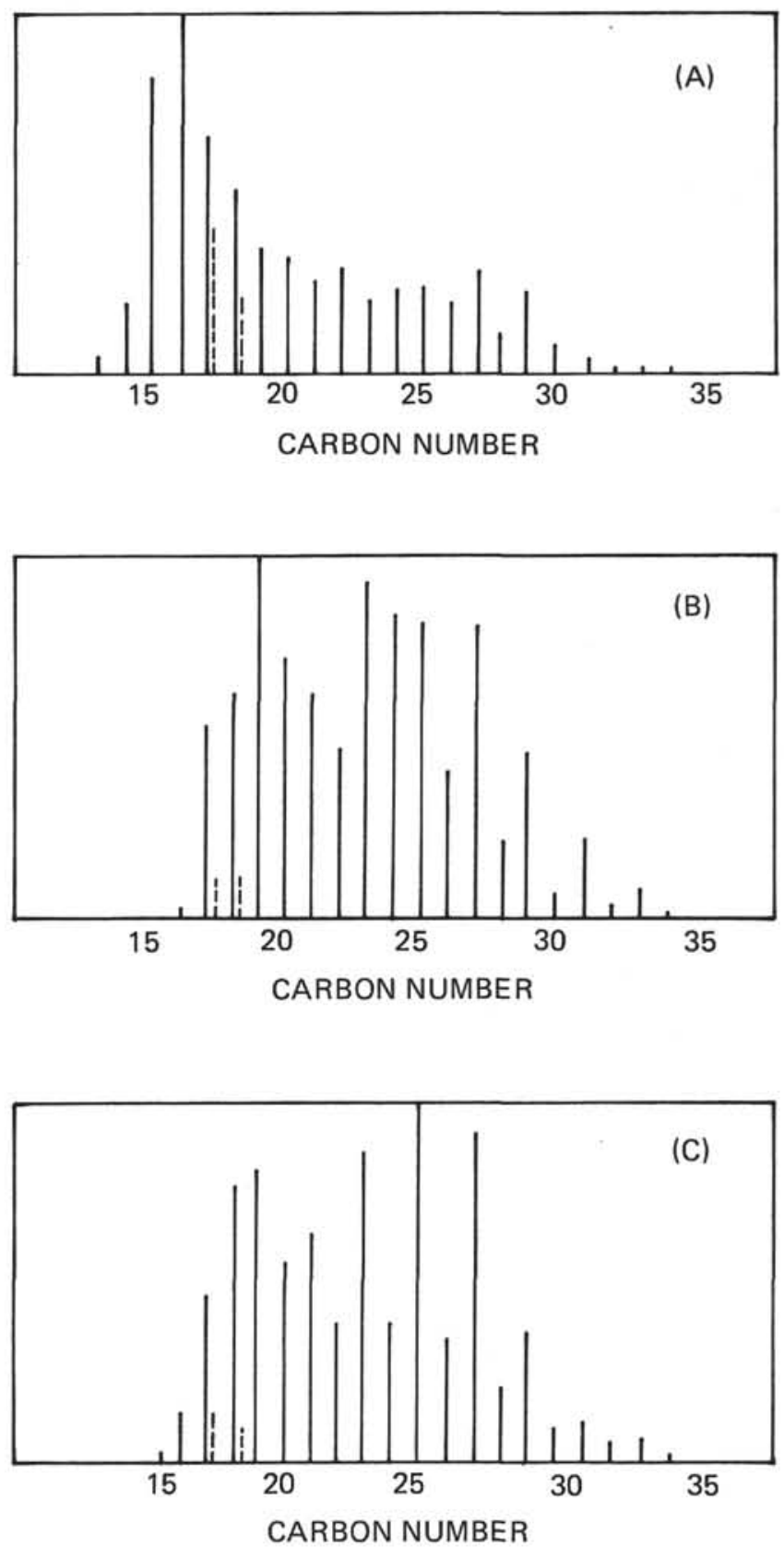

Figure 2. Distribution of n-alkanes (unbroken lines), pristane and phytane (broken lines) in core samples: $(A)$ 402A-18, (B) 402A-24, (C) 402A-30.

and of pristane and phytane (Figure 2) which are associated with a complex envelope of unresolved components not present in Cores 24 and 30. This suggests shipboard contamination of the composite Core 18. Low levels of pristane and phytane are present in Cores 24 and 30.

\section{Steranes and Sterenes}

Several rearranged sterenes $\left(\mathrm{I}, \mathrm{R}=\mathrm{H}, \mathrm{CH}_{3}, \mathrm{C}_{2} \mathrm{H}_{5}\right)$ were present as major components in all three samples, with a similar distribution; Figure 3 shows these components in Cores 24 and 30 by way of $\mathrm{m} / \mathrm{e} 257$ which is the base peak in the spectra of these compounds (Rubinstein et al., 1975). 

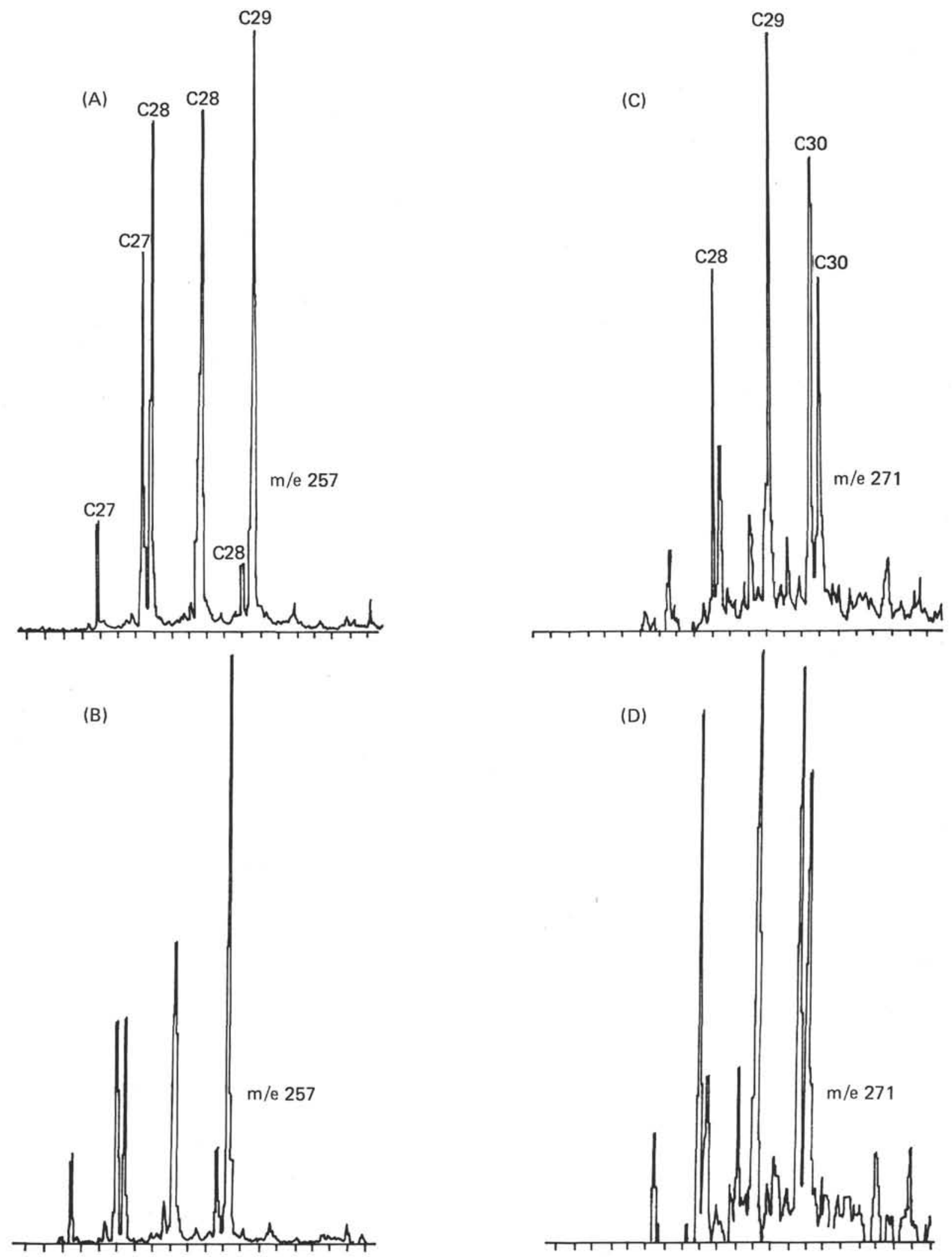

Figure 3. Partial mass fragmentograms of $m / e 257(A$ and $B$ ) and 271 (C and D) for aliphatic hydrocarbon fractions from Cores $402 A-24$ and $402 A-30$. 
The six major components in increasing order of elution are two $\mathrm{C}_{27}(\mathrm{I}, \mathrm{R}=\mathrm{H})$, three $\mathrm{C}_{28}\left(\mathrm{I}, \mathrm{R}=\mathrm{CH}_{3}\right)$ and one $\mathrm{C}_{29}$ $\left(\mathrm{I}, \mathrm{R}=\mathrm{C}_{2} \mathrm{H}_{5}\right)$ components. Tentative assignments were based on comparison of the mass spectra with literature examples (Rubinstein et al., 1975) GC-MS analyses of Core 18 were carried out before and after storage $\left(5^{\circ} \mathrm{C}, 8\right.$ weeks) in solvent; the fragmentogram of m/e 257 showed that the rearranged sterenes were virtually absent, presumably as a result of atmospheric oxidation. This emphasizes the necessity of rapid analysis and careful storage for these compounds.

In addition, a series of nuclear methylated rearranged sterenes (II) was observed in Cores 24 and 30 and were characterized (Rubenstein et al., 1975) by m/e 271 (Figure $3)$. The corresponding fragmentogram for Core 18 was not obtained prior to storage; after storage these components were virtually absent. In Cores 24 and 30 , the distributions were similar to each other. However, they occur as minor components, being present at ca. $1 / 15$ of the concentration of the rearranged sterenes. The full mass spectra showed that the four major components are a $\mathrm{C}_{28}(\Pi, \mathrm{R}=\mathrm{H})$ and three $\mathrm{C}_{29}$ (II, $\mathrm{R}=\mathrm{CH}_{3}$ ) compounds (Figure 3 ).

Steranes $(\mathrm{m} / \mathrm{e} 217)$ were present in only small quantities in all three samples; no sterenes (m/e 215 and m/e 213) were observed.

\section{Triterpenes and Triterpanes}

The distributions are again very similar in all three samples, as indicated by the fragmentograms for $\mathrm{m} / \mathrm{e} 191$ (see Figure 4 for Cores 24 and 30) and m/e 189 (not shown). The structural assignments of the major components are listed in Table 3 and the chemical structures ${ }^{2}$ appear at the end of the text in this chapter. The triterpanes were assigned by comparison of their mass spectra with those of standards, except for compound $\mathrm{R}$, which was assigned by spectral interpretation.

A series of $\mathrm{C}_{27}(\mathrm{III}, \mathrm{R}=\mathrm{H}), \mathrm{C}_{29}$ to $\mathrm{C}_{31}\left(\mathrm{III}, \mathrm{R}=\mathrm{C}_{2} \mathrm{H}_{5}\right.$, iso $-\mathrm{C}_{3} \mathrm{H}_{7}$, sec $-\mathrm{C}_{4} \mathrm{H}_{9}$ ) triterpenes, characterized by $\mathrm{M} *$, $\mathrm{M}+-15, \mathrm{~m} / \mathrm{e} 367, \mathrm{~m} / \mathrm{e} 231$, and $\mathrm{m} / \mathrm{e} 191$, were observed in all three samples. Only a spectrum of hop-17(21)-ene (Component G) was available for comparison, but Ensminger (1977), using the same criteria, also tentatively assigned components of this series in the Toarcian shales of the Paris Basin. The two $\mathrm{C}_{31}$ components ( $\mathrm{L}$ and $\mathrm{M}$ ) are presumably C-22 epimers (IIIa). 22,90,30-Trisnorhop17(21)-ene has only been identified to date in a surface marine sediment of the Norwegian Sea (Dastillung et al., $1977)$ and the $C_{29}$ component $(F)$ has not been reported previously.

Three other triterpenes $\left(\mathrm{C}_{27}, \mathrm{C}_{29}, \mathrm{C}_{30}\right)$ are also present in all of the samples. Compound $\mathrm{J}$ has a mass spectrum identical to that of neohop-13(18)-ene (IV, $\mathrm{R}=i s o-\mathrm{C}_{3} \mathrm{H}_{7}$ ). The spectra of the $\mathrm{C}_{27}$ and $\mathrm{C}_{29}$ components are similar to that of IV $\left(\mathrm{R}=i\right.$ iso $\left.-\mathrm{C}_{3} \mathrm{H}_{7}\right)$, except that $\mathrm{m} / \mathrm{e} 218$ is shifted to $\mathrm{m} / \mathrm{e} 204$ and $\mathrm{m} / \mathrm{e} 176$, respectively. It is, therefore, possible that both compounds have $\Delta^{13(18)}$ neohopene structures. However, the retention time of neohop-13(18)-ene is longer than that of hop-17(21)-ene, whereas the retention times for

${ }^{2}$ Each chemical structure is designated by a roman numeral. the proposed $\mathrm{C}_{27}$ and $\mathrm{C}_{29}$ compounds are reversed relative to their hop-17(21)-ene counterparts. Only the $\mathrm{C}_{30}$ compound has been identified to date in sediments, viz. the Toarcian shales of the Paris Basin (Ensminger, 1977).

\section{Aromatic Hydrocarbons}

A feature of these fractions is the gross similarity in the overall distributions of Cores 24 and 30 (Figure 5), although there are differences in the trace components (see below). In contrast, Core 18 , containing ca. 1/20 of total aromatic hydrocarbons shows significant differences in the distribution, for example, in the fragmentogram of $\mathrm{m} / \mathrm{e} 252$ (=e.g. $\mathrm{M} \div$ of perylene) (Figure 6 ). The major component in Core 18 was shown to be perylene, from the mass spectrum and co-injection with a standard, which is either absent or is a minor component of the other two. The major component in Cores 24 and 30 is an unknown aromatic hydrocarbon of molecular weight 218 .

Among the minor components a number of triterpenoid-derived compounds were tentatively assigned from comparison of their mass spectra with literature examples (Spyckerelle, 1975), although the distributions varied from sample to sample. These include structures VI (Core 24 only), VII (Cores 24 and 30), VIII (Cores 18 and $30)$, IX (Cpre 18 only). In addition, Cores 24 and 30 contain components whose spectra are consistent with nuclear-methylated aromatic hopanes as follows: structure $\mathrm{X}$ (two components in sample $24 ; \mathrm{M} \pm 360, \mathrm{M}-15, \mathrm{M}-29$ ) $\mathrm{XI}$ (two components in Sample 30; $\mathrm{M} \div 342, \mathrm{M}-15, \mathrm{M}-29$ ). Core 18 shows two components with $\mathrm{M}+=292$, whose spectra compare favorably with literature spectra of XII (Spyckerelle, 1975).

\section{Carboxylic Acids (FAME)}

Normal and Branched Alkanoic and Alkenoic Acids

The distributions of the three samples are dominated by components ranging from $n-\mathrm{C}_{10: 0}$ to $n-\mathrm{C}_{32: 0}$ maximizing at $n$-C16:0. In the deepest sample (402A-30) a greater relative abundance of long-chain acids is present (Figure 7) and $n$ - $\mathrm{C}_{24: 0}$ is only slightly less abundant than $n$ - $\mathrm{C}_{16: 0}$. Saturated branched acids, dominated by iso- and anteiso-Cis:o, are very minor components of all of the samples; acyclic isoprenoid acids are also present in very low concentrations. Two mono-unsaturated acids, $n-\mathrm{C}_{16: 1}$ and $n-\mathrm{C}_{18: 1}$, were detected at all three levels, but their concentrations were considerably less than those of the corresponding saturated acids; the low concentrations precluded assignment of the position and geometry of the double bond, and the concentration of the two compounds decreased with increasing depth. No polyunsaturated fatty acids were detected.

\section{Triterpanoic and Triterpenoic Acids}

Triterpanoic acids belonging to three series of the hopane family were detected as major components in the FAME from all three depths (Table 4). There is a similar distribution in each case, as shown by the fragmentograms of $\mathrm{m} / \mathrm{e} 191$ (Figure 8) although the greatest similarity is in Cores 18 and 24; the $\mathrm{C}_{32}$ components are of greater abundance relative to their $\mathrm{C}_{31}$ and $\mathrm{C}_{33}$ counterparts in Core 30. Structural assignments were based on the characteristic 


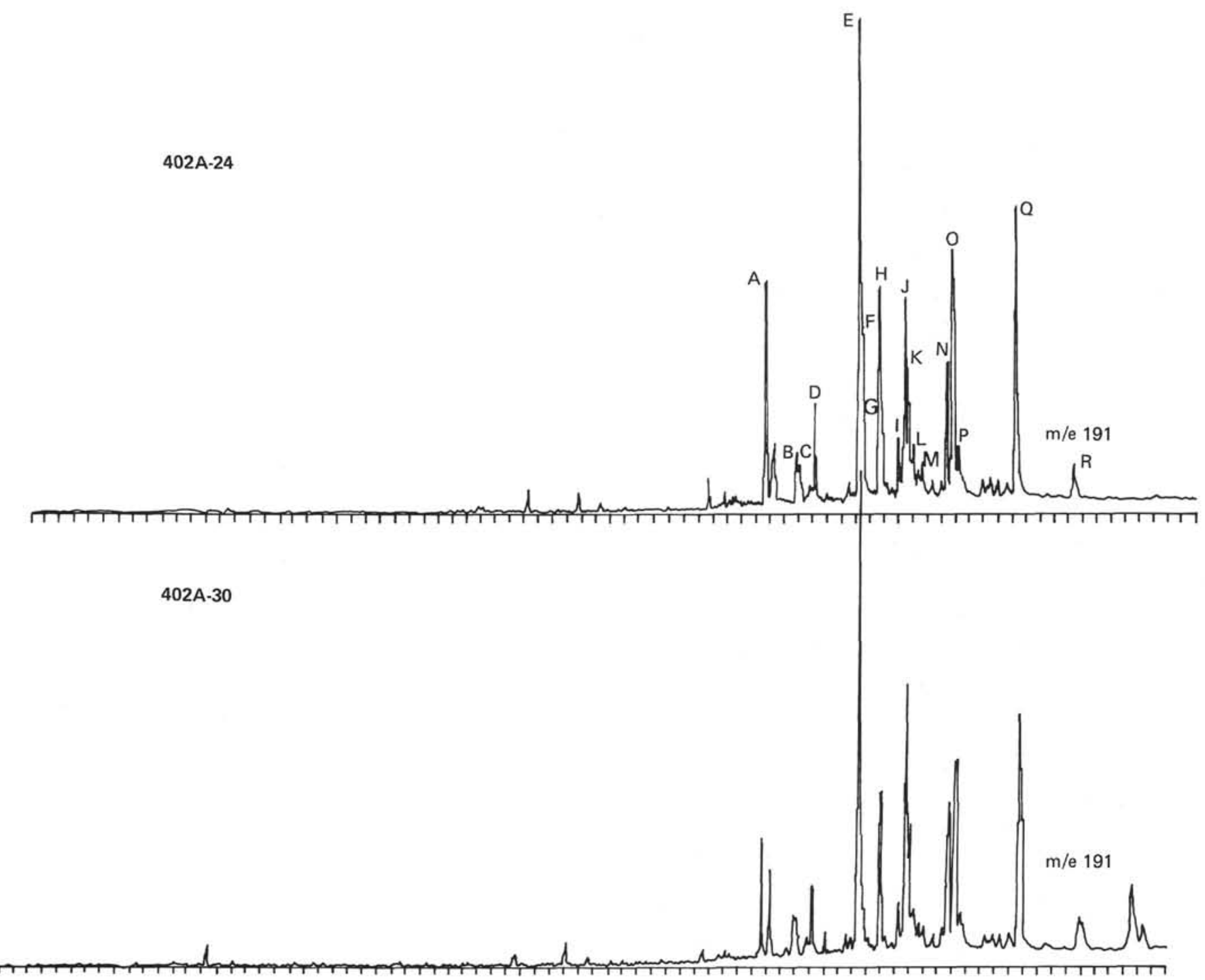

Figure 4. Mass fragmentograms of m/e 191 for aliphatic hydrocarbons in Cores 402A-24 and 30.

ions $\mathrm{M}^{+}, \mathrm{M}^{+}-15, \mathrm{M}^{+}$-side chain, $\mathrm{m} / \mathrm{e} 191, \mathrm{~m} / \mathrm{e} 148+\mathrm{R}$ (where $\mathrm{R}=$ the substituent on Ring $\mathrm{E}$ ). The three series $(17 \alpha \mathrm{H}, 21 \beta \mathrm{H} ; 17 \beta \mathrm{H}, 21 \alpha \mathrm{H} ; 17 \beta \mathrm{H}, 21 \beta \mathrm{H})$ were distinguished by the relative abundances of the ions $\mathrm{m} / \mathrm{e} 191$ and $\mathrm{m} / \mathrm{e} 148+\mathrm{R}$ (Van Dorsselaer, 1975). In all three samples, $17 \beta \mathrm{H}, 21 \beta \mathrm{H}$-bis-homohopanoic acid (XIIIb) is the major triterpenoid acid (Figure 8). Table 4 lists the compounds assigned in Core 402A-30 from their full mass spectra, and they appear to be present in Cores 18 and 24 from comparison of full mass spectra (where obtained), retention data and the distributions in the $\mathrm{m} / \mathrm{e} 191$ fragmentograms (Figure 8): the $\mathrm{C}_{31}, \mathrm{C}_{32}, \mathrm{C}_{33}$ members of the $17 \alpha \mathrm{H}, 21 \beta \mathrm{H}$ series (components $\mathrm{A}, \mathrm{E}, \mathrm{H}$; XIIIa,b,c), the $\mathrm{C}_{31}, \mathrm{C}_{32}, \mathrm{C}_{33}$ members of the $17 \beta \mathrm{H}, 21 \alpha \mathrm{H}$ series (components C, G., J; XIIIa,b,c), and the $\mathrm{C}_{31}, \mathrm{C}_{33}, \mathrm{C}_{34}$ members of the $17 \beta \mathrm{H}, 21 \beta \mathrm{H}$ series (components $\mathrm{F}, \mathrm{K}, \mathrm{L}$; $\mathrm{XIII}, \mathrm{c}, \mathrm{d})$. In Cores 18 and 30 a component showing the characteristic fragment ions (m/e 191 and m/e 235) for a $\mathrm{C}_{30}$ triterpanoic acid (methyl ester) was detected but no $\mathrm{M}$. was obtained.

At all three depths, two mono-unsaturated $\mathrm{C}_{32}$ triterpenoid acids were present in virtually the same relative proportions to each other (Table 4). The spectra (e.g., Figure 9) show $\mathrm{M}^{+}=\mathrm{m} / \mathrm{e} 482, \mathrm{M}^{+}-15,367\left(\mathrm{M}^{+}\right.$-side chain), $231(100 \%)$, and 191 and are consistent with the compounds being bis-homohop-17(21)-enoic acids (XIV). Compounds of this type have not been reported in organisms or sediments although Ensminger (1977) reported a series $\left(\mathrm{C}_{30}-\mathrm{C}_{35}\right)$ of $\Delta^{17(21)}$ alkenes in the Toarcian shales of the Paris Basin. The two compounds appear to be stereoisomers but the position at which they are isomeric is not known. In Core 30 , two other $\mathrm{C}_{32}$ mono-unsaturated triterpenoic acids were observed.

\section{Hydroxy Carboxylic Acids (OH FAME)}

Complex mixtures of more polar acids were found in each of the three samples. Silylation of the mixtures indicated the presence of a number of hydroxy acids which was confirmed by fragmentograms for $\mathrm{m} / \mathrm{e} 73,75$, and 89 . From the full spectra, a series of $\alpha$-hydroxy acids ranging from $n-\mathrm{C}_{11: 0}$ to $n-\mathrm{C}_{22: 0}$, maximizing at $n-\mathrm{C}_{14: 0}$, was identified in Core 18 , but was not observed in the deeper samples. The distribution is unusual in that even chain length compounds are only slightly more abundant than the odd chain length 
TABLE 3

Aliphatic Triterpenoid Hydrocarbons of Cores 402A-18, 402A-24, and 402A-30

\begin{tabular}{|c|c|c|}
\hline Peak $^{\mathrm{a}}$ & Diagnostic Ions (\%) & Tentative Assignment $^{\mathrm{b}}$ \\
\hline A & $\mathrm{M}: 368,353,191(100), 187(50), 176(90), 163(70)$ & 22,29,30-Trisnorneohop-13(18)-ene $(\mathrm{IV}, \mathrm{R}=\mathrm{H})^{\mathrm{c}}$ \\
\hline B & $\mathrm{M} \pm 368,353,231(75), 191(100)$ & $22,29,30$-Trisnorhop-1 7(21)-ene $(\mathrm{III}, \mathrm{R}=\mathrm{H})^{\mathrm{c}}$ \\
\hline $\mathrm{C}$ & $\mathrm{M}: 370,355,191(100), 149(40)$ & $17 \alpha \mathrm{H}-22,29,30$-Trisnorhopane $(\mathrm{V}, \mathrm{R}=\mathrm{H})$ \\
\hline $\mathrm{D}$ & $\mathrm{M}: 370,355,191(70), 149(100)$ & 22,29,30-Trisnorhopane $(\mathrm{V}, \mathrm{R}=\mathrm{H})$ \\
\hline $\mathrm{E}$ & $\mathrm{M}^{+}: 396,381,367(2), 204(45), 191(100), 189(40)$ & 30-Norneohop-13(18)-ene $\left(\mathrm{IV}, \mathrm{R}=\mathrm{C}_{2} \mathrm{H}_{5}\right)^{\mathrm{c}}$ \\
\hline $\mathrm{F}$ & $\mathrm{M}: 396,381,367(22), 231(65), 191(100), 189(30)$ & 30-Norhop-17(21)-ene (III, $\left.\mathrm{R}=\mathrm{C}_{2} \mathrm{H}_{5}\right)^{\mathrm{c}}$ \\
\hline G & $\mathrm{M} \pm 410,395,367(100), 231(95), 191(70), 189(50)$ & Hop-17(21)-ene (III, R= iso- $\left.\mathrm{C}_{3} \mathrm{H}_{7}\right)$ \\
\hline $\mathrm{H}$ & $\mathrm{M} \pm 398,383,191(90), 177(100)$ & 30-Normoretane $\left(\mathrm{V}, \mathrm{R}=\mathrm{C}_{2} \mathrm{H}_{5}, 21 \alpha \mathrm{H}\right)$ \\
\hline $\mathbf{I}$ & $\mathrm{M} \pm 412,397,191(100)$ & $\mathrm{C}_{30}$ triterpane \\
\hline $\mathrm{J}$ & $\mathrm{M}: 410,395,367(5), 218(45), 205(47), 191(100)$ & Neohop-13(18)-ene (IV, $\left.\mathrm{R}=\underline{\text { iso- }} \mathrm{C}_{3} \mathrm{H}_{7}\right)$ \\
\hline $\mathrm{K}$ & $\mathrm{M} \div 398,383,191(50), 177(100)$ & 30-Norhopane $\left(\mathrm{V}, \mathrm{R}=\mathrm{C}_{2} \mathrm{H}_{5}\right)$ \\
\hline $\mathbf{L}$ & $\mathrm{M} \pm 424,409,367(60), 231(100), 191(95), 189(50)$ & Homohop-17(21)-ene $\left(\mathrm{III}, \mathrm{R}=\mathrm{sec}_{-}-\mathrm{C}_{4} \mathrm{H}_{9}\right)^{\mathrm{c}}$ \\
\hline M & $\mathrm{M} \pm 424,409,367(85), 231(100), 191(80), 189(40)$ & Homohop-17(21)-ene $\left(\mathrm{III}, \mathrm{R}=\mathrm{sec}^{-} \mathrm{C}_{4} \mathrm{H}_{9}\right)^{\mathrm{c}}$ \\
\hline $\mathrm{N}$ & $\mathrm{M}+426,411,369(2), 205(28), 191(100)$ & $17 \alpha \mathrm{H}$-homohopane $\left(\mathrm{V}, \mathrm{R}=\mathrm{sec}-\mathrm{C}_{4} \mathrm{H}_{9}\right)$ \\
\hline o & $\mathrm{M}: 412,397,369(4), 191(100)$ & Hopane $\left(\mathrm{V}, \mathrm{R}=\right.$ iso $\left.-\mathrm{C}_{3} \mathrm{H}_{7}\right)$ \\
\hline $\mathbf{P}$ & $\mathrm{M} \div 426,411,369(5), 205(80), 191(100)$ & Homomoretane $\left(\mathrm{V}, \mathrm{R}=\mathrm{sec}-\mathrm{C}_{4} \mathrm{H}_{9}, 21 \alpha \mathrm{H}\right)$ \\
\hline Q & $M \pm 426,411,369(5), 205(100), 191(50)$ & Homohopane $\left(\mathrm{V}, \mathrm{R}=\mathrm{sec}^{-\mathrm{C}_{4}} \mathrm{H}_{9}\right)$ \\
\hline $\mathrm{R}$ & $\mathrm{M} \div 440,425,219(100), 191(55)$ & Bishomohopane $\left(\mathrm{V}, \mathrm{R}=\mathrm{sec}-\mathrm{C}_{5} \mathrm{H}_{11}\right)^{\mathrm{c}}$ \\
\hline
\end{tabular}

a See Figure 4.

${ }^{b}$ From comparison with standard spectra, unless otherwise stated.

${ }^{\mathrm{c}}$ Identification based on spectral interpretation.
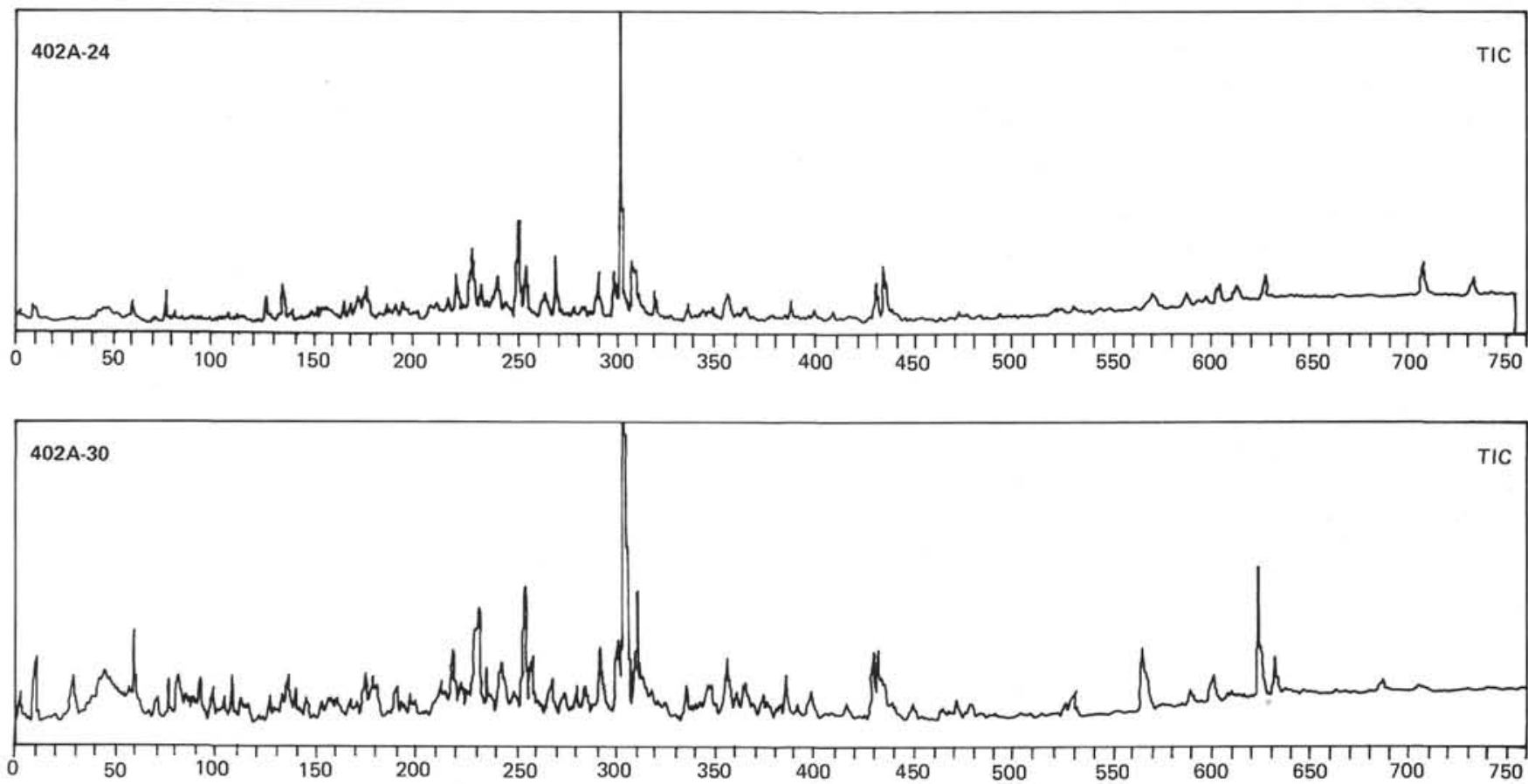

Figure 5. Total ion current traces of aromatic hydrocarbon fractions from Cores 402A-24 and 30.

components. $\beta$-Hydroxy acids are only minor components of the OH FAME, and only in the case of $n-\mathrm{C}_{14: 0}$ could positive evidence be obtained from the mass spectral data. No evidence for significant quantities of $\omega$ - or polyhydroxy acids was obtained.

\section{DISCUSSION}

\section{Straight and Branched Chain Components}

The $n$-alkanes and $n$-alkanoic acids (Figures 2 and 7) show bimodal distributions. The odd/even predominance in 


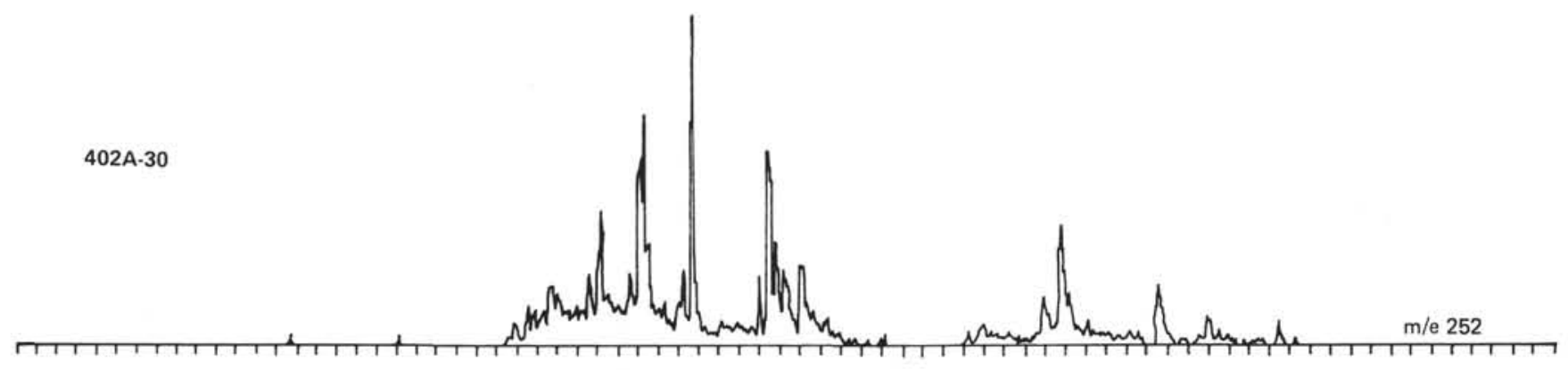

402A-18

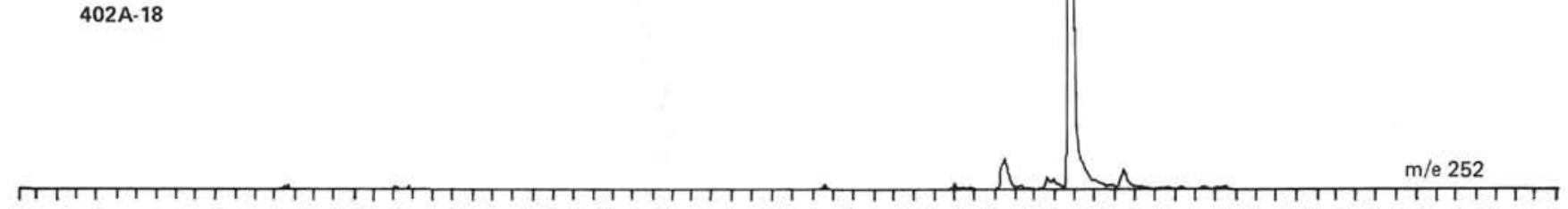

Figure 6. Mass fragmentograms of m/e 252 for the aromatic hydrocarbon fractions from Cores $402 \mathrm{~A}-18$ and 30 .

the higher $n$-alkanes $\left(>\mathrm{C}_{21}\right)$ is indicative of a higher plant contribution, as is the even/odd predominance in the longer chain $n$-alkanoic acids $\left(>\mathrm{C}_{20}\right)$. The major difference between the three samples in this carbon number range is the greater proportion of higher plant-derived components in Core 402A-30, presumably reflecting a slightly greater contribution of such organisms.

The absence of a unimodal distribution of $n$-alkanes with $\mathrm{CPI} \simeq 1$ reflects the known (Deroo et al., this volume) immaturity of the samples. Similarly, the absence of a particularly abundant $n-\mathrm{C}_{17}$ alkane is in agreement with either a low algal input to the forming sediments or extensive bacterial degradation at that time. It is difficult to distinguish these two possibilities: the former is in agreement with the low abundance of morphologically recognizable algal debris (Doran et al., this volume). The latter situation has been observed in a depth study of contemporary algal mats (Cardoso et al., 1976).

The presence of high relative abundances of iso- and anteiso-acids is typically taken as evidence of a bacterial contribution to sediments (e.g., Leo and Parker, 1976). The occurrence of low relative concentrations in the samples from Hole 402A is, however, unlikely to be the result of low bacterial input because many gram-negative species (particularly abundant in the marine environment) often show low abundances of these acids relative to $C_{16: 0}, C_{16: 0}$, $\mathrm{C}_{\text {18:0 }}, \mathrm{C}_{18: 1}$ (Oliver and Colwell, 1973).

Although the major input to the samples is thought to derive from higher plants (Deroo et al., this volume), no evidence for significant quantities of long chain $\omega$-hydroxy or polyhydroxy acids could be obtained; such components are typical of higher plant cutin and suberin (Hunneman and Eglinton, 1972). This suggests that little or no hydrolysis of these plant biopolymers has occurred during diagenesis. Examination of the bound hydroxy acids is in progress.

\section{Cyclic Components}

The most striking feature of the sterenes, triterpenoid alkanes and alkenes, and triterpanoic and triterpenoic acids is the similarity in the distributions of each of these structurally specific classes in all three samples. These similarities suggest that the environments of deposition of the black shale layers were similar although the periodic deposition was separated by a time span of up to ca. $7 \times 10^{6}$ years.

The high relative abundance of unsaturated components to saturated components is again in agreement with the immaturity of the sediments.

The occurrence of high relative abundances of $\Delta$ 13(17) rearranged sterenes (I) is noteworthy. The presence of these diagenetic products of sterols is thought to indicate the presence of acidic conditions within immature sediments (Dastillung and Albrecht, 1977).

The distribution of triterpanes is as expected for an immature sediment, with the thermodynamically less stable $17 \beta \mathrm{H}$ components predominating over their $17 \alpha \mathrm{H}$ counterparts (e.g., Ensminger et al., 1977).

The distribution of triterpene hydrocarbons in the samples is unusual in that a number of the components have not been reported previously to occur in sediments: the $\Delta{ }^{13(18)}$ alkenes; 22,29,30-trisnorneohop-13(18)-ene (IV, $\mathrm{R}=\mathrm{H}$ ) and 30-norneohop-13(18)-ene (IV, $\mathrm{R}=\mathrm{C}_{2} \mathrm{H}_{5}$ ); and 30-norhop-17(21)-ene. If the proposed assignments of the $\Delta{ }^{13(18)}$ components are correct, their occurrence may relate to the reported conversion of hop-17(21)-ene (III, R = iso $-\mathrm{C}_{3} \mathrm{H}_{7}$ ) to the corresponding $\Delta^{13(18)}$ rearranged hopene skeleton (IV, $\mathrm{R}=$ iso $-\mathrm{C}_{3} \mathrm{H}_{7}$ ) under acidic conditions (Berti and Bottari, 1968). This is borne out by the co-occurrence of the $\mathrm{C}_{27}, \mathrm{C}_{29}$, and $\mathrm{C}_{30}$ members of each series.

In an analogous manner to the triterpenoid hydrocarbons, the predominance of the $17 \beta \mathrm{H}$ components and the presence 

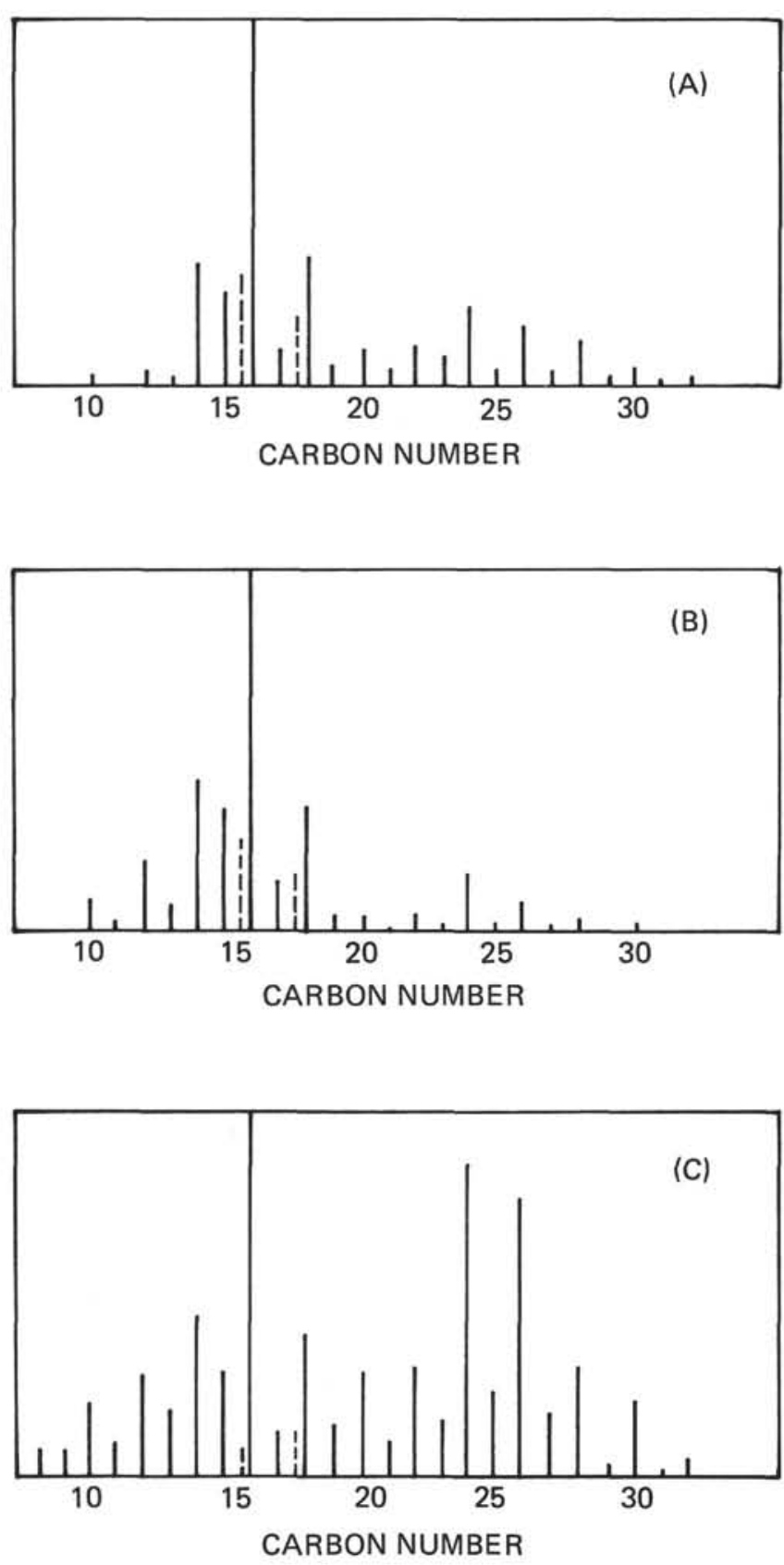

Figure 7. Distributions of $\mathrm{n}$-alkanoic (unbroken lines), $\mathrm{n}-C_{16: 1}$, and $\mathrm{n}-C_{18: 1}$ (dotted lines) acids in core samples: (A) 402A-18, (B) 402A-24, (C) 402A-30.

of triterpenoic acids reflects the immaturity of all three samples (Ensminger, 1977).

Triterpenoid-derived aromatic hydrocarbons have not been reported to occur in the biosphere; in the sediments they are, therefore, likely to be diagenetic products formed at low temperatures. In contrast to the aliphatic triterpenoids, the distributions show differences among the samples. These differences appear to relate either to depositional environment or to diagenetic alteration, or both: (1) Core 18 contrasts with 24 and 30 in that no nuclear-methylated compounds are present. This must reflect a difference in input by way of nuclear-methylated
TABLE 4

Triterpenoid Acids of Core 402A-30

\begin{tabular}{|c|c|c|}
\hline Peak $^{\mathrm{a}}$ & Diagnostic Ions & Tentative Assignment $(\mathrm{ACD})^{\mathrm{b}}$ \\
\hline A & $M_{4}^{+} 470,455,369(3), 249(64), 191(100)$ & $17 \alpha \mathrm{H}, 21 \beta \mathrm{H}$-homohopanoic (XIIIa) \\
\hline B & $\mathrm{M}^{ \pm} 4882,467,367(41), 231(100), 191(84)$ & Bishomohop-17(21)-enoic (XIV) \\
\hline C & $\mathrm{M}^{ \pm} 470,455,369(4), 249(84), 191(100)$ & $17 \beta \mathrm{H}, 21 \alpha \mathrm{H}$-homohopanoic (XIIIa) \\
\hline D & $\mathrm{M}^{ \pm} 4882,467,367(57), 231(100), 191(83)$ & Bishomohop-17(21)-enoic (XIV) \\
\hline $\mathrm{E}$ & $M \div 484,469,369(4), 263(29), 191(100)$ & 17 $\alpha \mathrm{H}, 21 \beta \mathrm{H}$-bishomohopanoic (XIIIb) \\
\hline $\mathrm{F}$ & $\mathrm{M}^{ \pm} 4470,455,369(5), 249(100), 191(73)$ & $17 \beta \mathrm{H}, 21 \beta \mathrm{H}$-homohopanoic (XIIIa) \\
\hline G & $\mathrm{M}^{ \pm} 4484,469,369(9), 263(85), 191(100)$ & $17 \beta \mathrm{H}, 21 \alpha \mathrm{H}$-bishomohopanoic (XIIIb) \\
\hline H & $\mathrm{M}^{ \pm} \div 498,483,369(3), 277(30), 191(100)$ & $17 \alpha \mathrm{H}, 21 \beta \mathrm{H}$-trishomohopanoic (XIIIc) \\
\hline I & $\mathrm{M}^{ \pm} 4484,469,369(9), 263(100), 191(67)$ & $17 \beta \mathrm{H}, 21 \beta \mathrm{H}$-bishomohopanoic (XIIIb) \\
\hline $\mathbf{J}$ & $\mathrm{M}^{ \pm} 4498,483,369(13), 277(100), 191(94)$ & $17 \beta \mathrm{H}, 21 \alpha \mathrm{H}$-trishomohopanoic (XIIIc) \\
\hline $\mathrm{K}$ & $M^{ \pm} 4498,483,369(7), 277(100), 191(65)$ & $17 \beta \mathrm{H}, 21 \beta \mathrm{H}$-trishomohopanoic (XIIIc) \\
\hline L & $M^{ \pm}: 512,497,369(4), 291(100), 191(69)$ & $17 \beta \mathrm{H}, 21 \beta \mathrm{H}-\mathrm{C}_{34}(\mathrm{XIIId})$ \\
\hline
\end{tabular}

precursor triterpenoids, (2) taken with the overall similarity in total aromatic hydrocarbon distributions in Cores 24 and 30 (Figure 5), the presence in 30 of components VII, VIII and XI with 2 or 3 aromatic rings, rather than the analogs VI, VII, and X ( 1 or 2 aromatic rings) in 24 , suggests a progressive aromatization with depth, (3) Core 18 alone shows two minor components (tentatively assigned as XII) whose skeletons are compatible with an origin in higher plant terpenoid precursors, and a high relative abundance of perylene.

Unfortunately, insufficient paleontological and sedimentary data are available for Cores 402A-18, 24, and 30 in order to relate the differences in the distributions of the aromatic hydrocarbons to these data. The triterpenoids of the hopane family found in sediments are thought to arise from tetra- and pentahydroxy bacteriohopanes (e.g., XV) (e.g., Van Dorsselaer et al., 1974), which have been shown to be major constituents of bacteria and blue-green algae (e.g., Rohmer and Ourisson, 1976); in the marine situation, where blue-green algae are not dominant in the phytoplankton, the likely source of hopane triterpenoids is bacteria. This is borne out by the low concentrations of visibly distinguishable algal debris in samples from Hole $402 \mathrm{~A}$ (Doran et al., this volume). The only compounds which could be assigned to a higher plant origin are the high molecular weight $n$-alkanes and $n$-alkanoic acids in all three cores, and the minor components XII in Core 18. It is perhaps surprising that only traces of cyclic diterpenoid components were observed (e.g., from m/e 191 fragmentograms in Figures 4 and 8 ). The majority of the compounds assigned in the solvent-soluble lipid fractions are compatible with a bacterial origin. This contrasts with the terrigenous origin proposed for the bulk of the organic matter (Deroo et al., 1977) and therefore suggests extensive bacterial contribution and possible reworking at the time of deposition.

\section{ACKNOWLEDGMENTS}

We thank the Natural Environment Research Council (GR3/2951) for support, and the National Aeronautics and Space Administration (subcontract from NGL 05-003-003), and the Nuffield Foundation for additional funding. AMKW acknowledges receipt of a Research Studentship from the Science Research Council; JM and SCB Research Studentships from the NERC. We wish to thank Mrs. A.P. Gowar for assistance with the GC-MS analyses. 


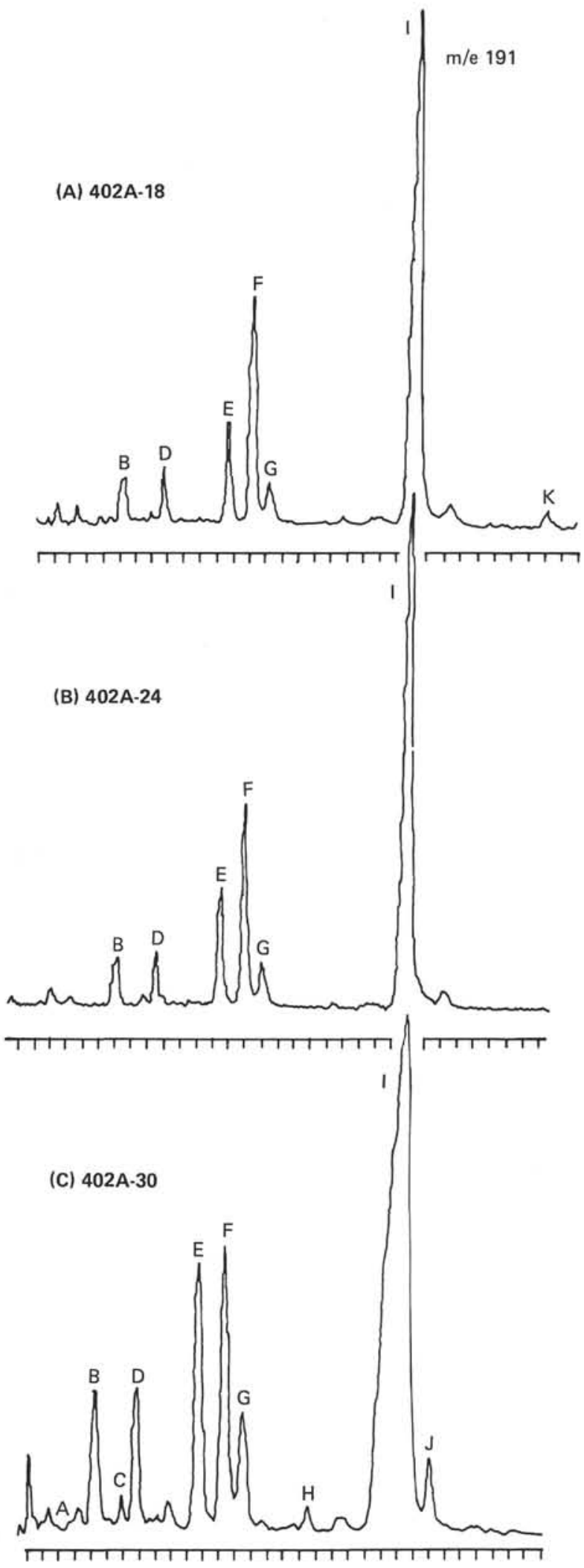

Figure 8. Partial mass fragmentograms of m/e 191 in FAME from core samples (A) 402A-18, (B) 402A-24, (C) 402A-30. Component $K$ is also present in 402A-24 and 30 , as is component $L$ in $402 A-30 ; K$ is not shown in 24 and 30 because of its longer $t_{R}$ in these two runs. 


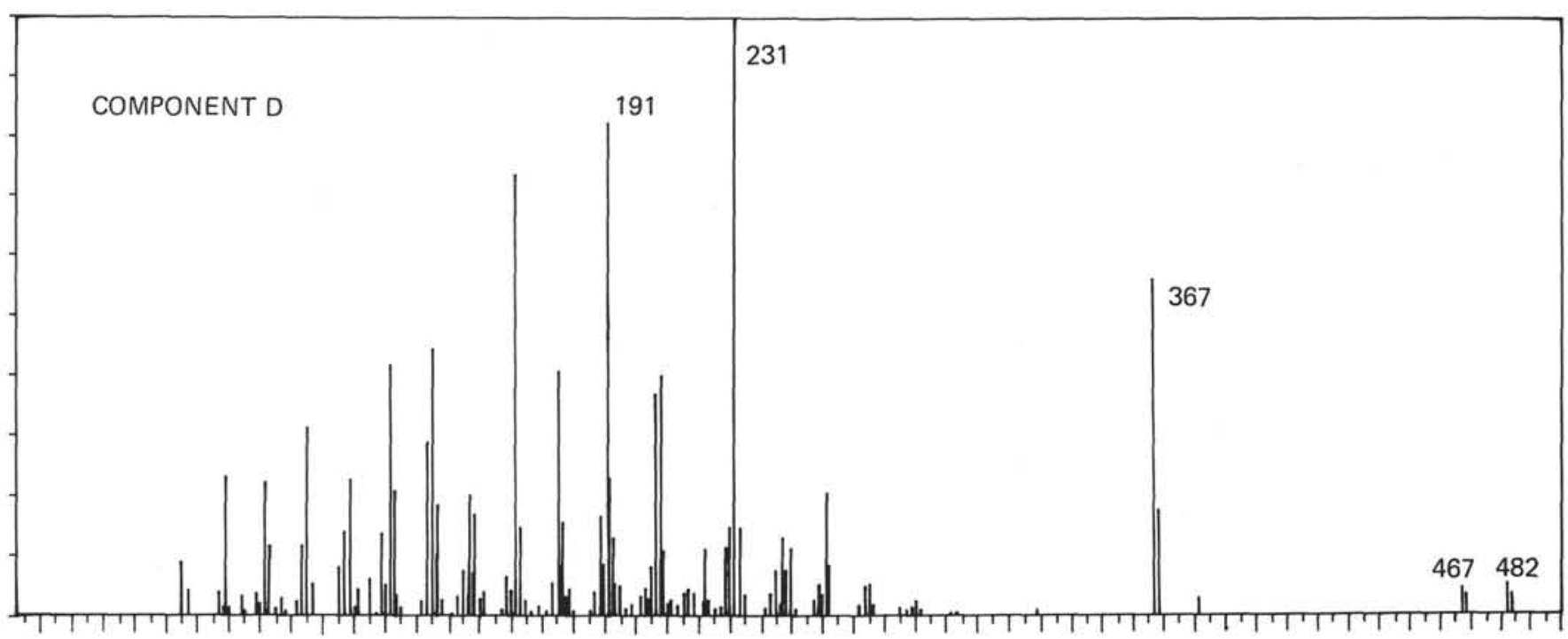

Figure 9. Mass spectrum of component D in FAME of Core 402A-30.

\section{REFERENCES}

Berti, G. and Bottari, F., 1968. Constituents of ferns, Progress in Phytochemistry, v. 1, p.590-685.

Cardoso, J., Brooks, P.W., Eglinton, G., Goodfellow, R., Maxwell, J.R., and Philp, R.P., 1976. Lipids of recently deposited algal mats at Laguna Mormona, Baja California. In Nriagu, J. (Ed.), Environmental biogeochemistry: Ann Arbor (Ann Arbor Science), p. 149-174.

Dastillung, M. and Albrecht, P., 1977. $\Delta^{2}$ Sterenes as diagenetic Hydrocarbures saturés et unsaturés des sédiments: Géochemique organique des sédiments marins profonds. Orgon 1, Mer de Norvège: Paris (Editions du CNRS), p. 209-228.

Dastillung, M., and Albrecht, P., 1977. $\Delta^{2}$ Sterenes as diagenetic intermediates in sediments, Nature, v. 269, p.678-679.

Ensminger, A., 1977. Evolution de composes polycycliques sédimentaires, Ph.D. thesis, Université Louis Pasteur, Strasbourg.

Ensminger, A., Albrecht, P., Ourisson, G., and Tissot, B., 1977. Evolution of polycyclic alkanes under effect of burial (Early Toarcian shales, Paris basin). In Campos, R., and Goni, J. (Eds.), Advances in organic geochemistry, 1975: Madrid (ENADIMSA), p. 375-391.

Hunneman, D.H., and Eglinton, G., 1972. Gas chromatographic-mass spectrometric studies of long-chain hydroxy acids
IV. The constituent acids of gymnosperm cutins, Phytochemistry, v. 11, p. 1989-2001.

Leo, R.F, and Parker, P.L., 1966. Branched-chain fatty acids in sediments, Science, v. 152, p. 1463.

Oliver, J.D. and Colwell, R.R., 1973. Extractable lipids of gram-negative marine bacteria. Fatty acid composition, International Journal of Systematic Bacteriology, v.23, p. 442-458.

Rohmer, M. and Ourisson, G., 1976. Structure des bacteriohopanetetrols d'Acetobacter xylinum, Tetrahedron Letters, v. 40 , p. 3633.

Rubinstein, I., Seiskind, O., and Albrecht, P., 1975. Rearranged sterenes in a shale: occurrence and simulated formation, Journal of the Chemical Society, Perkin I, p. 1833-1836.

Spyckerelle, C., 1975. Constituants aromatiques de sédiments, Ph.D. Thesis, Université Louis Pasteur, Strasbourg.

Van Dorsselaer, A., Ensminger, A., Spyckerelle, C., Dastillung, M., Seiskind, O., Arpino, P., Ourisson, G., Brooks, P.W., Gaskell, S.J., Kimble, B.J., Philp, R.P., Maxwell, J.R., and Eglinton, G., 1974. Degraded and extended hopane derivatives $\left(\mathrm{C}_{27}-\mathrm{C}_{35}\right)$ as ubiquitous geochemical markers, Tetrahedron Letters, v. 14, p. 1349-1352.

Van Dorsselaer, A., 1975. Triterpènes de sédiments, Ph.D. Thesis, Université Louis Pasteur, Strasbourg. 


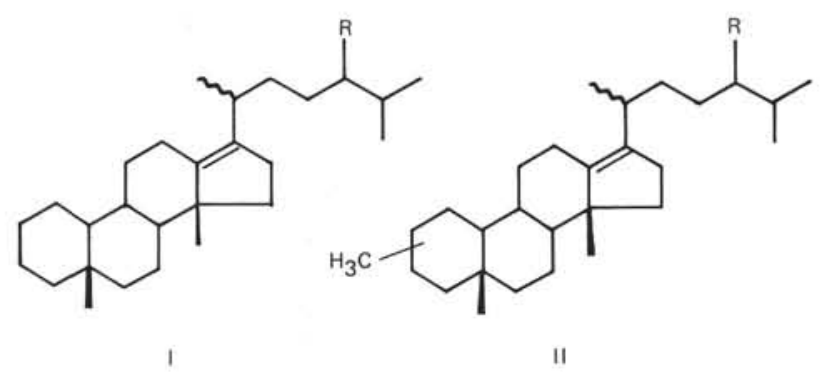<smiles>[R]C1=C2CCC3C4(C)CCCC(C)(C)C4CCC3(C)C3CCC(C4(C)CCC(C)C4=C1C)C3(C)CC2</smiles>

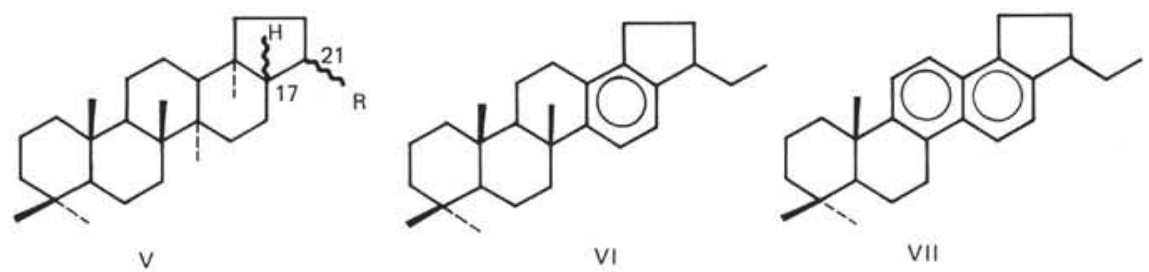

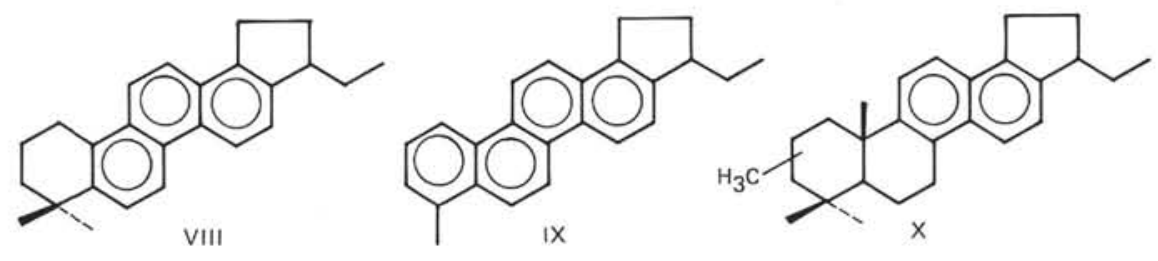<smiles>CCC1CCc2c1ccc1c2ccc2c3c(ccc21)C(C)(C)CCC3</smiles><smiles>CCC1CCC2c3ccc4c(C)cccc4c3CCC2(C)C1</smiles>

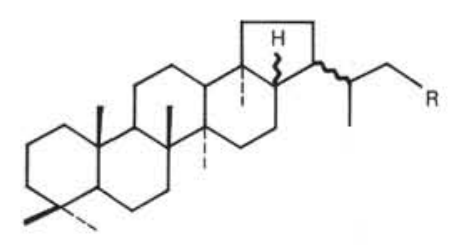<smiles>CC(CCC(=O)O)C1=C2CCC3(C)C(CCC4C5(C)CCCC(C)(C)C5CCC43C)C2CC1</smiles>

XIIIa, $\mathrm{R}=\mathrm{CO}_{2} \mathrm{H} ; \mathrm{b}, \mathrm{R}=\mathrm{CH}_{2} \mathrm{CO}_{2} \mathrm{H}$; c, $\mathrm{R}=\left(\mathrm{CH}_{2}\right)_{2} \mathrm{CO}_{2} \mathrm{H} ; \mathrm{d}, \mathrm{R}=\left(\mathrm{CH}_{2}\right)_{3} \mathrm{CO}_{2} \mathrm{H}$

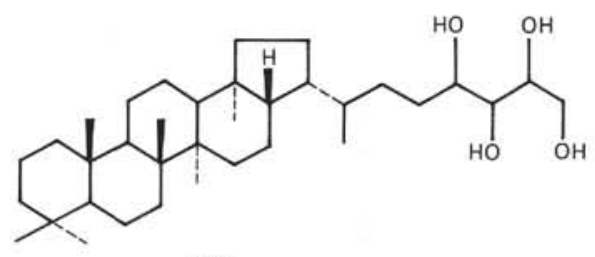

